\title{
The histamine $\mathrm{H}_{4}$ receptor: from orphan to the clinic
}

\author{
Robin L. Thurmond * \\ Janssen Research \& Development, LLC, San Diego, CA, USA
}

The histamine $\mathrm{H}_{4}$ receptor $\left(\mathrm{H}_{4} \mathrm{R}\right)$ was first noted as a sequence in genomic databases that had features of a class A G-protein coupled receptor. This putative receptor was found to bind histamine consistent with its homology to other histamine receptors and thus became the fourth member of the histamine receptor family. Due to the previous success of drugs that target the $\mathrm{H}_{1}$ and $\mathrm{H}_{2}$ receptors, an effort was made to understand the function of this new receptor and determine if it represented a viable drug target. Taking advantage of the vast literature on the function of histamine, a search for histamine activity that did not appear to be mediated by the other three histamine receptors was undertaken. From this asthma and pruritus emerged as areas of particular interest. Histamine has long been suspected to play a role in the pathogenesis of

OPEN ACCESS

Edited by:

Ye Fang,

Corning Incorporated, USA

Reviewed by:

Nora Ibargoyen,

Basque Office for Health Technology

Assessment, Spain

Domenico Criscuolo,

Genovax, Italy

${ }^{*}$ Correspondence:

Robin L. Thurmond,

Janssen Research \& Development,

LLC, 3210 Merryfield Row,

San Diego, CA 92121, USA

rthurmon@its.jnj.com

Specialty section:

This article was submitted to

Pharmaceutical Medicine and

Outcomes Research, a section of the

journal Frontiers in Pharmacology

Received: 14 January 2015

Paper pending published:

12 February 2015

Accepted: 12 March 2015

Published: 31 March 2015

Citation:

Thurmond RL (2015) The histamine $\mathrm{H}_{4}$ receptor: from orphan to the clinic.

Front. Pharmacol. 6:65.

doi: 10.3389/fphar.2015.00065 asthma, but antihistamines that target the $\mathrm{H}_{1}$ and $\mathrm{H}_{2}$ receptors have not been shown to be effective for this condition. The use of selective ligands in animal models of asthma has now potentially filled this gap by showing a role for the $\mathrm{H}_{4} \mathrm{R}$ in mediating lung function and inflammation. A similar story exists for chronic pruritus associated with conditions such as atopic dermatitis. Antihistamines that target the $\mathrm{H}_{1}$ receptor are effective in reducing acute pruritus, but are ineffective in pruritus experienced by patients with atopic dermatitis. As for asthma, animal models have now suggested a role for the $\mathrm{H}_{4} \mathrm{R}$ in mediating pruritic responses, with antagonists of the $\mathrm{H}_{4} R$ reducing pruritus in a number of different conditions. The anti-pruritic effect of $\mathrm{H}_{4} \mathrm{R}$ antagonists has recently been shown in human clinical studies, validating the preclinical findings in the animal models. A selective $\mathrm{H}_{4} \mathrm{R}$ antagonist inhibited histamine-induced pruritus in health volunteers and reduced pruritus in patients with atopic dermatitis. The history to date of the $\mathrm{H}_{4} \mathrm{R}$ provides an excellent example of the deorphanization of a novel receptor and the translation of this into clinical efficacy in humans.

Keywords: histamine, atopic dermatitis, pruritus, asthma, arthritis

\section{Introduction}

There are now four known G-coupled protein receptors (GPCRs) that use histamine as a ligand. These receptors were discovered over a span of almost 100 years and each discovery provides excellent examples of the use of state-of-the-art receptor pharmacology to discovery new receptors. The first actions of histamine were noted around 1910 (Barger and Dale, 1910; Dale and Laidlaw, 1911), but this before the idea of receptors was widely accepted. After the development of compounds that blocked the effect of histamine in the 1930-1940s, it was noted that their effects were consistent with a competition for binding at a receptor now known as the histamine $\mathrm{H}_{1}$ receptor 
$\left(\mathrm{H}_{1} \mathrm{R}\right.$; Wells et al., 1945). These first antihistamines became the basis for very successful drugs, some of which are still in use today. However, they also revealed new questions since there were actions of histamine that were not blocked by these ligands. This led to the proposal that a second histamine receptor existed (Ash and Schild, 1966), and the discovery of selective ligands for this receptor led to its pharmacological characterization and the designation as the $\mathrm{H}_{2} \mathrm{R}$ (Black et al., 1972). A similar story exist for the discovery of the $\mathrm{H}_{3} \mathrm{R}$, where it was noted that various histamine receptor ligands modulated histamine actions in the brain, but that the pharmacology did not match the known $\mathrm{H}_{1} \mathrm{R}$ and $\mathrm{H}_{2} \mathrm{R}$ (Arrang et al., 1983).

\section{Discovery of the Histamine $\mathrm{H}_{4}$ Receptor}

However, by the 1990s novel receptors were discovered mainly by the identification of their gene sequence and less so by their pharmacology. The cloning of the receptor cDNA for the human $\mathrm{H}_{1} \mathrm{R}$ and $\mathrm{H}_{2} \mathrm{R}$ were described in the early 1990s (Gantz et al., 1991; De Backer et al., 1993), but the sequence of the $\mathrm{H}_{3} \mathrm{R}$ remained elusive despite much work looking for sequences with similarity to the $\mathrm{H}_{1} \mathrm{R}$ and $\mathrm{H}_{2} \mathrm{R}$. The breakthrough came using a different approach where sequences were identified that contained general homologies to GPCR (e.g., predicted seven transmembrane domains and other common residues). These putative orphan GPCR genes were then screened for binding to likely ligands. Using such an approach, a novel sequence was discovered that encoded a GPCR that bound to histamine and had pharmacology that matched that described for the $\mathrm{H}_{3} \mathrm{R}$ (Lovenberg et al., 1999). The details of the sequence revealed why the gene for the $\mathrm{H}_{3} \mathrm{R}$ was not found by a homology approach, since it only exhibited $\sim 20 \%$ homology to the $\mathrm{H}_{1} \mathrm{R}$ and $\mathrm{H}_{2} \mathrm{R}$.

While the cloning of the $\mathrm{H}_{3} \mathrm{R}$ used an orphan GPCR/reverse pharmacology approach, it yielded a receptor that was already known and characterized on a pharmacological basis. The discovery of the $\mathrm{H}_{4} \mathrm{R}$ truly started with the identification of an orphan GPCR. The discovery of the gene for the $\mathrm{H}_{3} \mathrm{R}$ provided a tool for additional homology searches of databases for related sequences. This yielded a putative receptor that was $\sim 35 \%$ identical to the $\mathrm{H}_{3} \mathrm{R}$ and when expressed in heterologous systems was found to have a high affinity for histamine (Liu et al., 2001). These genomic approaches were so prevalent at the time that the identification of this new receptor, now known as the histamine $\mathrm{H}_{4}$ receptor $\left(\mathrm{H}_{4} \mathrm{R}\right)$, was described almost simultaneously by six different laboratories (Nakamura et al., 2000; Oda et al., 2000; Liu et al., 2001; Morse et al., 2001; Nguyen et al., 2001; Zhu et al., 2001). Unlike the $\mathrm{H}_{3} \mathrm{R}$, the $\mathrm{H}_{4} \mathrm{R}$ was completely novel and its function was unknown. However, one hint of function was evident from the expression pattern described in the original cloning papers that showed a fairly selective expression on bone marrow and hematopoietic cells known to be involved in inflammatory and immune responses.

\section{Development of Selective Ligands}

The identification of a novel histamine receptor, its expression mainly on cells involved in immune responses coupled with the successful history of drugs that target the $\mathrm{H}_{1} \mathrm{R}$ and $\mathrm{H}_{2} \mathrm{R}$ generated immediate interest (Hough, 2001). However, deorphanizing the receptor was only the beginning. Importantly, selective ligands were needed to be able to understand the function of the receptor. The receptor has a relatively high homology to the $\mathrm{H}_{3} \mathrm{R}$ and thus it is not surprising that many of the compounds previously described as $\mathrm{H}_{3} \mathrm{R}$ ligands also had affinity for the $\mathrm{H}_{4} \mathrm{R}$ (Liu et al., 2001). These ligands included (R)- $\alpha$-methylhistamine, an $\mathrm{H}_{3} \mathrm{R}$ agonist, and thioperamide, an $\mathrm{H}_{3} \mathrm{R}$ antagonists, but because these ligands had affinity for both receptors they are not ideal tools for understanding the function of the $\mathrm{H}_{4} \mathrm{R}$. The first potent and selective $\mathrm{H}_{4} \mathrm{R}$ antagonist was JNJ 7777120 (Jablonowski et al., 2003). This compound has a high affinity for the $H_{4} \mathrm{R}$ and is highly selective relative to other histamine receptors (Thurmond et al., 2004).

JNJ 7777120 has become an excellent tool for understanding the physiological role of the $\mathrm{H}_{4} \mathrm{R}$ and has been used extensively in vitro cell models and in animal models. The use of JNJ 7777120 in vivo provided the first evidence that $\mathrm{H}_{4} \mathrm{R}$ antagonists could have anti-inflammatory properties. Neutrophil influx in a mouse peritonitis model was reduced upon pretreatment with JNJ 7777120 (Thurmond et al., 2004). Early work also showed that JNJ 7777120 and its analog, JNJ 10191584, were also efficacious in a rat colitis model (Varga et al., 2005). This compound along with other $\mathrm{H}_{4} \mathrm{R}$ antagonists have shown activity in models of asthma, dermatitis, pain, and pruritus among others (Table 1; Dunford et al., 2006, 2007; Cowden et al., 2010b; Hsieh et al., 2010).

As evidenced by the pharmacology of the other histamine receptors, it is important not to rely on the data provided by a single ligand when assigning function to a particular receptor. The reason for this is that despite the best efforts it is almost impossible to completely understand the pharmacology of any ligand and how it may differ in different species, cell types, or conditions. Because of these factors, researchers must use a combination of tools including agonist/antagonist pairs, ligands from different chemical classes, and/or knockout animals before making conclusions about the function of receptor. The use of a single ligand only gives firm conclusions about the action of that ligand under the given experimental conditions.

This has been highlighted as a potential issue with JNJ 7777120 as it has been described as having agonistic effects at the $\mathrm{H}_{4} \mathrm{R}$ of some species in some, but not all, transfected cell models and has been described to drive functional selectivity, i.e., arrestin activation, of the $\mathrm{H}_{4} \mathrm{R}$ (Seifert et al., 2011). However, while these other pharmacological effects may exist, most of the current data support the fact that JNJ 7777120 is an antagonist in vivo and in primary cells. For example the effects on JNJ 7777120 in models of asthma, dermatitis, arthritis, pain, and peritonitis are consistent to those of other distinct $\mathrm{H}_{4} \mathrm{R}$ ligands and in $\mathrm{H}_{4} \mathrm{R}$-deficient mice (Table 2; Thurmond et al., 2004, 2014a; Dunford et al., 2006; Coruzzi et al., 2007; Altenbach et al., 2008; Cowart et al., 
TABLE 1 | Effects of $H_{4} R$ antagonists in selected animal models ${ }^{1}$.

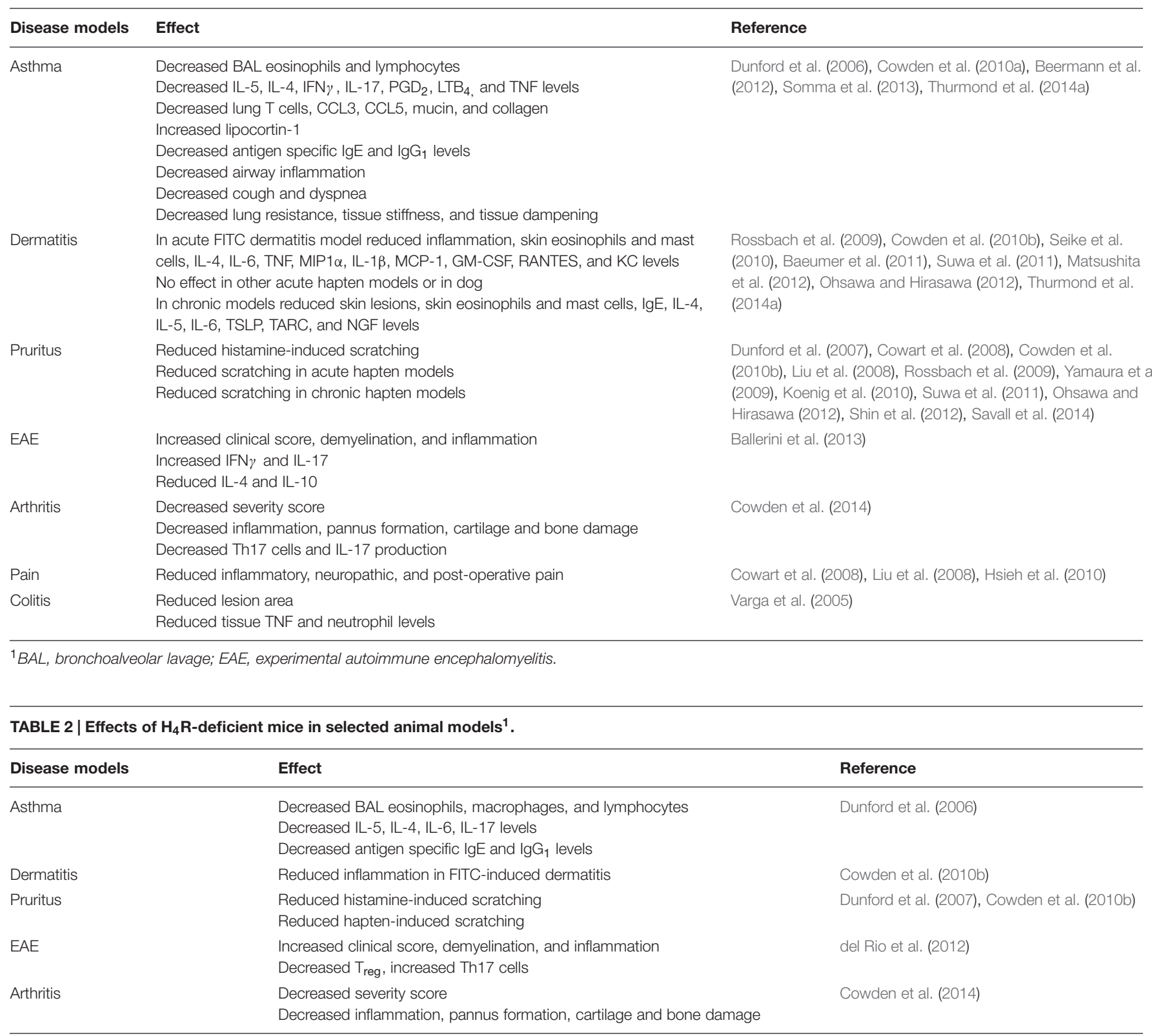

${ }^{1} B A L$, bronchoalveolar lavage; $E A E$, experimental autoimmune encephalomyelitis.

2008; Liu et al., 2008; Cowden et al., 2010b, 2014; Hsieh et al., 2010; Shin et al., 2012; Savall et al., 2014). Perhaps one of the best examples of this is in the role of the receptor in mediating pruritic responses in mice. Dunford et al. (2007) reported that histamine-induced scratching in mice could be blocked by JNJ 77777120 and did not occur in $\mathrm{H}_{4} \mathrm{R}$-deficient mice. Furthermore, other $\mathrm{H}_{4} \mathrm{R}$ agonists also induce scratching that can be blocked by JNJ 7777120, but cannot induce scratching in $\mathrm{H}_{4} \mathrm{R}$-deficient mice (Dunford et al., 2007; Yu et al., 2010). Other $\mathrm{H}_{4} \mathrm{R}$ antagonists with different chemical structure also block this response (Cowart et al., 2008; Liu et al., 2008; Koenig et al., 2010; Shin et al., 2012; Savall et al., 2014). The data then clearly support the role of JNJ 77777120 as an antagonist for this effect. The compound reverses the effect of agonists, mimics the findings in animal lacking the $\mathrm{H}_{4} \mathrm{R}$ and the results are replicated by other antagonists. However, this cannot be generalized. For example JNJ 7777120 also has been shown to block substance P induced itch (Yamaura et al., 2009) and while is it appropriate to speculate that $\mathrm{H}_{4} \mathrm{R}$ activation is involved in substance $\mathrm{P}$ induced itch based on data in other models, it would take studies in $\mathrm{H}_{4} \mathrm{R}$ deficient mice or with other structurally distinct antagonist to firmly conclude this.

Some of the in vivo data also yield insight as to the role of functional selectivity at the $\mathrm{H}_{4} \mathrm{R}$. In the models of pruritus, asthma, and dermatitis the phenotype is the same between JNJ 7777120-treated and $\mathrm{H}_{4} \mathrm{R}$-deficient mice (Dunford et al., 2006, 
2007; Cowden et al., 2010b). This suggests that if the induction of $\beta$-arrestin shown by Rosethorne and Charlton (2011) occurs in mice (currently functional selectivity has only been studied for the human receptor), it has little impact on the activity of the compound in these models. For if JNJ 7777120-induced arrestin pathways are anti-inflammatory then they would not exist in the receptor deficient animals. Once again the most likely explanation is that the compound functions as an antagonist of the receptor. This does not mean, however, that the possibility of functional selectivity should be dismissed and it may suggest that antagonists could be created that only block a subset of the pathways activated by the receptor.

\section{Function}

Much of the original expression data obtained with the $\mathrm{H}_{4} \mathrm{R}$ pointed to expression on cells involved in immune responses. In conjunction with this, researchers took advantage that the ligand for this orphan receptor was histamine and thus searched the extensive literature on histamine to find functions mediated by histamine, but where the pharmacology did not clearly point to the $\mathrm{H}_{1} \mathrm{R}, \mathrm{H}_{2} \mathrm{R}$, or $\mathrm{H}_{3} \mathrm{R}$. One example of this was in eosinophils. In Clark et al. (1975) showed that histamine could induce chemotaxis of human eosinophils at low concentrations, $10^{-7}$ and $10^{-6} \mathrm{M}$, but that at $10^{-5} \mathrm{M}$ chemotaxis was reduced. They showed that neither mepyramine (an $\mathrm{H}_{1} \mathrm{R}$ antagonist) nor metiamide (an $\mathrm{H}_{2} \mathrm{R}$ antagonist) had any effect on the enhanced chemotaxis, but that metiamide reversed the inhibition of chemotaxis at $10^{-5} \mathrm{M}$. They concluded that the stimulation of chemotaxis by histamine was independent of $\mathrm{H}_{1} \mathrm{R}$ and $\mathrm{H}_{2} \mathrm{R}$ and in a later paper concluded that a third histamine receptor existed on eosinophils (this was prior to the discovery of the $\mathrm{H}_{3} \mathrm{R}$; Clark et al., 1977). Raible et al. (1992) showed that histamine induced a calcium response in eosinophils and, as observed for chemotaxis, this effect was not inhibited by an $\mathrm{H}_{1} \mathrm{R}$ antagonist (mepyramine) or an $\mathrm{H}_{2} \mathrm{R}$ antagonist (cimetidine). The calcium response was inhibited by thioperamide which was described as an antagonist of the newly discovered $\mathrm{H}_{3} \mathrm{R}$. In addition (R)- $\alpha$ methylhistamine, an $\mathrm{H}_{3} \mathrm{R}$ agonist, induced a calcium response similar to that of histamine. However, the authors commented that the fact that $(\mathrm{R})-\alpha$-methylhistamine was less potent than histamine suggested that this calcium response was not mediated by a classic $\mathrm{H}_{3} \mathrm{R}$ since at this receptor histamine is more potent than (R)- $\alpha$-methylhistamine. In a later study Raible et al. (1994) confirm this unusual pharmacology with a series a different $\mathrm{H}_{3} \mathrm{R}$ antagonists and agonists. The identity of this novel histamine receptor remained a mystery (or was perhaps ignored) until the discovery of the gene for the $\mathrm{H}_{4} \mathrm{R}$. It was noted that the pharmacological profile of the $\mathrm{H}_{4} \mathrm{R}$ was similar to the receptor described by Raible et al. (1994; Oda et al., 2000; Hough, 2001; Liu et al., 2001; Morse et al., 2001; Zhu et al., 2001; O'Reilly et al., 2002). In particular, burimamide is a weak $H_{4} \mathrm{R}$ partial agonist (Zhu et al., 2001; Lim et al., 2005), while (R)- $\alpha$-methylhistamine and $N$-methylhistamine are both full agonist (Nakamura et al., 2000; Oda et al., 2000; Liu et al., 2001; Morse et al., 2001; Zhu et al., 2001), but are less potent than histamine thus matching the conflicting pharmacology described by Raible et al. (1992, 1994). The role of the $\mathrm{H}_{4} \mathrm{R}$ in mediating histamine-induced eosinophil chemotaxis and calcium responses was confirmed once selective ligands became available. Selective $\mathrm{H}_{4} \mathrm{R}$ antagonists (e.g., JNJ 7777120) have been shown to block histamine-induced chemotaxis and calcium responses (Ling et al., 2004; Strakhova et al., 2009; Reher et al., 2012; Shin et al., 2012). Chemotaxis of eosinophils can also be studied indirectly by measuring shapechange related to actin reorganization that precedes chemotaxis (Sabroe et al., 1999). Histamine and selective $\mathrm{H}_{4} \mathrm{R}$ agonists such as 4-methylhistamine and others have been shown to induce eosinophil shape change and this can be blocked by $\mathrm{H}_{4} \mathrm{R}$ selective antagonists (Ling et al., 2004; Lim et al., 2005; Yu et al., 2010; Shin et al., 2012; Thurmond et al., 2014a).

The histamine-induced eosinophil shape change was used as a pharmacodynamics readout for a clinical study with JNJ 39758979 (Thurmond et al., 2014a). After oral dosing of the compound to healthy volunteers, blood samples were taken at various timepoints, stimulated with histamine and the shape change of the eosinophils was assessed. At doses and time points where the concentration of JNJ 39758979 was above $100 \mathrm{nM}$, a statistically significant inhibition was observed. This level of potency was similar to what when the compound was added to blood in vitro (Thurmond et al., 2014a). These results show that in vivo administration of an $\mathrm{H}_{4} \mathrm{R}$ antagonist in humans can have impact on eosinophil function.

The initial idea that a new histamine receptor was present on eosinophils came about because of differences in the pharmacology of various histamine ligands. Not only were $\mathrm{H}_{1} \mathrm{R}$ and $\mathrm{H}_{2} \mathrm{R}$ ligands ineffective, but the potency of $\mathrm{H}_{3} \mathrm{R}$ ligands was not as expected (Raible et al., 1994). Therefore, it is important to evaluate the pharmacological data with the $\mathrm{H}_{4} \mathrm{R}$ ligands carefully. First, it has been noted that the potency for eosinophil function of the various $\mathrm{H}_{4} \mathrm{R}$ ligands (either selective or non-selective) compared to histamine is in general agreement with their relative affinities thus supporting that this is in fact the $\mathrm{H}_{4} \mathrm{R}$ (Buckland et al., 2003; Ling et al., 2004; Lim et al., 2005; Yu et al., 2010; Reher et al., 2012). Furthermore, the $\mathrm{K}_{\mathrm{i}}$ for antagonists can be calculated from studies where the $\mathrm{EC}_{50}$ of histamine is given using modifications of the Cheng and Prusoff (1973) equation. Ling et al. (2004) report IC $_{50}$ values for JNJ 7777120 and thioperamide for eosinophil shape change and chemotaxis. One can use these values along with the concentration and $\mathrm{EC}_{50}$ for histamine to calculate $\mathrm{K}_{\mathrm{i}}$ values of 5 and $4 \mathrm{nM}$ for JNJ 7777120 and 26 and $26 \mathrm{nM}$ for thioperamide for inhibiting histamine-induced eosinophil shape change and chemotaxis, respectively. These numbers are similar to the reported Ki values from recombinant systems for JNJ 7777120 (4 nM) and thioperamide (27 nM; Liu et al., 2001; Thurmond et al., 2004). Consistent with this Barnard et al. (2008) report an $\mathrm{IC}_{50}$ of JNJ 7777120 of $6 \mathrm{nM}$ that corresponds to a calculated $\mathrm{K}_{\mathrm{i}}$ value of $2 \mathrm{nM}$. However, Seifert et al. (2011) have stated incorrectly that the discrepancy in the $\mathrm{IC}_{50}$ values for JNJ 7777120 between the Ling et al. (2004) and Barnard et al. (2008) studies (300 versus $6 \mathrm{nM}$ ) support the notion of functional selectivity for the $\mathrm{H}_{4} \mathrm{R}$ in eosinophils. However, the authors fail to take into account the differences in $\mathrm{EC}_{50}$ for 
histamine $19 \mathrm{nM}$ for Ling et al. (2004) and $150 \mathrm{nM}$ for Barnard et al. (2008), which when properly accounted for yields almost identical $K_{i}$ values for JNJ 7777120 (5 nM versus $2 \mathrm{nM}$ ). The differences in the $\mathrm{EC}_{50}$ for histamine between the two studies is most likely due to large differences in histamine response related to $\mathrm{H}_{4} \mathrm{R}$ levels between difference donors as reported by $\mathrm{Yu}$ et al. (2010).

The effect of JNJ 7777120 on the histamine calcium response in eosinophils yields the same conclusion with a reported $\mathrm{K}_{\mathrm{i}}$ value of $1.3 \mathrm{nM}$ (Reher et al., 2012). However, these same authors report a discrepancy in the $\mathrm{K}_{\mathrm{i}}$ values for JNJ 7777120 with respect to chemotaxis. The calculated $K_{i}$ for JNJ 7777120 was $9.8 \mathrm{nM}$ when histamine was used to induce chemotaxis, but $1.6 \mathrm{nM}$ when a selective $\mathrm{H}_{4} \mathrm{R}$ agonist was used, UR-PI376 (Reher et al., 2012). They use this data as "evidence for ligand-specific receptor conformation" as the title states. However, the authors fail to account for the role of the $\mathrm{H}_{2} \mathrm{R}$ in inhibiting chemotaxis. The $\mathrm{K}_{\mathrm{i}}$ value of $9.8 \mathrm{nM}$ is calculated using the $\mathrm{EC}_{50}$ of histamine $(120 \mathrm{nM})$, but this is not a true $\mathrm{EC}_{50}$ since the dose response curve is made up of two components - one for the $\mathrm{H}_{4} \mathrm{R}$ response and one for the $\mathrm{H}_{2} \mathrm{R}$ response. Indeed when the authors block the $\mathrm{H}_{2} \mathrm{R}$ with famotidine, the $\mathrm{EC}_{50}$ of histamine is reduced to $39 \mathrm{nM}$. Recalculating the $\mathrm{K}_{\mathrm{i}}$ for JNJ 7777120 using this $\mathrm{EC}_{50}$, which represents the true $\mathrm{H}_{4} \mathrm{R}$ response, yields a value of $3.2 \mathrm{nM}$ that is completely consistent with the value when using the $\mathrm{H}_{4} \mathrm{R}$-selective agonist and the value reported by Ling et al. (2004). Furthermore, this value is similar to the $K_{i}$ value the authors report for the histamine-induced calcium response because there is no $\mathrm{H}_{2} \mathrm{R}$ contribution to the calcium signal as shown in the paper (Reher et al., 2012). Therefore, the effects seen by $\mathrm{H}_{4} \mathrm{R}$ ligands on eosinophil responses are entirely consistent with the known pharmacology of the $\mathrm{H}_{4} \mathrm{R}$ and no functional selectivity needs to be invoked.

Histamine is largely associated with mast cells since these cells store and secrete large amounts of histamine. Therefore, it was natural early to look for $\mathrm{H}_{4} \mathrm{R}$ effects in mast cells. One of the major functions of mast cells it to release inflammatory mediators such as histamine upon IgE-mediated degranulation. However, in mouse bone marrow-derived mast cells, neither genetic deficiency (mast cells taken from $\mathrm{H}_{4} \mathrm{R}$-deficient mice) nor the $\mathrm{H}_{3} \mathrm{R} / \mathrm{H}_{4} \mathrm{R}$ antagonist thioperamide had any effect on antigenmediated degranulation (Hofstra et al., 2003). The $\mathrm{H}_{4} \mathrm{R}$ does appear to modulate degranulation indirectly by inducing upregulation of high affinity IgE receptors, FceRI (Mirzahosseini et al., 2013). In addition to this, in human mast cells histamine and 4-methylhistamine on their own were able in induced degranulation and in both cases this could be blocked with JNJ 7777120 (Jemima et al., 2014). As for eosinophils, histamine acting via the $\mathrm{H}_{4} \mathrm{R}$ can induce increases in intracellular calcium. This histamine-induced calcium response is not present in mast cells from $\mathrm{H}_{4} \mathrm{R}$-deficient mice and can be blocked by thioperamide or JNJ 7777120 (Hofstra et al., 2003; Thurmond et al., 2004; Jemima et al., 2014). $\mathrm{H}_{4} \mathrm{R}$ agonists can also induce calcium responses in these cells ( $Y u$ et al., 2010; Jemima et al., 2014). Also similar to eosinophils, histamine-induced chemotaxis can be observed in mast cells. This effect was not observed with mast cells deficient in the $\mathrm{H}_{4} \mathrm{R}$ and can be blocked by antagonist of the $\mathrm{H}_{4} \mathrm{R}$, but not the other histamine receptors (Hofstra et al., 2003; Thurmond et al., 2004, 2014a). As for the eosinophil data the $\mathrm{IC}_{50}$ values for $\mathrm{H}_{4} \mathrm{R}$ antagonist was consistent with measured values indicating that the effects seen are due to $\mathrm{H}_{4} \mathrm{R}$ antagonism (Thurmond et al., 2004, 2014a). Changes in cell shape related to chemotaxis can also be measured and blocked by $\mathrm{H}_{4} \mathrm{R}$ antagonists (Strakhova et al., 2009). Consistent with this, the $\mathrm{H}_{4} \mathrm{R}$ agonist 4methylhistamine can induce chemotaxis and this effect is blocked by JNJ 7777120 (Lim et al., 2005). In addition, histamine has also been shown to potentiate the migration of human precursor mast cells to the chemoattractant CXCL12 (Godot et al., 2007). The histamine-induced migration of mast cells may be related to the accumulation of mast cells at sites of inflammation. It has been shown that inhalation of histamine by mice leads to an accumulation of subepithelial mast cells in the trachea and this was reversed upon pretreatment with JNJ 7777120 (Thurmond et al., 2004). The number of mast cells increases in the skin in mouse dermatitis models and in vivo treatment with JNJ 7777120 blocked this accumulation (Cowden et al., 2010b; Seike et al., 2010; Suwa et al., 2011; Matsushita et al., 2012; Ohsawa and Hirasawa, 2012). In addition to inducing chemotaxis, the $\mathrm{H}_{4} \mathrm{R}$ also enhances inflammatory mediator production from mast cells. In mouse mast cells, histamine and 4-methylhistamine were both able to induce IL- 6 production on their own and potentiate the IL- 6 production driven by LPS stimulation. These effects were mediated via the $\mathrm{H}_{4} \mathrm{R}$ since they could be blocked by $\mathrm{H}_{4} \mathrm{R}$ antagonists and were not present in $\mathrm{H}_{4} \mathrm{R}$-deficient mice (Desai and Thurmond, 2011). In human mast cells the $\mathrm{H}_{4} \mathrm{R}$ mediated the release of leukotrienes, cytokines, and chemokines (Jemima et al., 2014).

The effects on mast cells and eosinophils pointed to allergic diseases such atopic dermatitis and asthma. The FITC-induced dermatitis model in mice is a contact dermatitis model, but unlike other models is characterized by eosinophilia. Mice deficient in the $\mathrm{H}_{4} \mathrm{R}$, have reduced inflammation in this model as judged by a reduction in inflammatory cytokines and chemokines in the skin and a reduction in swelling at the site of FITC challenge (the ear; Cowden et al., 2010b). Several different $\mathrm{H}_{4} \mathrm{R}$ antagonists also show the same effect (Cowden et al., 2010b; Thurmond et al., 2014a). At the site of FITC application there is a increase in both the number of eosinophils and mast cells in the skin. Treatment of the mice systemically with JNJ 7777120 was able to reduce, and for mast cells completely block, this increase (Cowden et al., 2010b). The $\mathrm{H}_{4} \mathrm{R}$ does no play a role in all acute dermatitis models. For example, no effect was observed with $\mathrm{H}_{4} \mathrm{R}$ antagonists in an acute canine atopic dermatitis model or when 2,4-dinitrochlorobenzene or toluene-2,4-diisocyanate were used as the hapten in mice (Rossbach et al., 2009; Baeumer et al., 2011). The same lack of effect was reported with JNJ 7777120 in an acute model using the hapten 2,4,6-trinitro-1-chlorobenzene (TNCB; Seike et al., 2010). However, when TNCB was given chronically the administration of JNJ 7777120 reduced the inflammation, the levels of inflammatory cytokines, and the number of mast cells and eosinophils in the skin (Seike et al., 2010; Suwa et al., 2011; Matsushita et al., 2012). A reduction in inflammation by JNJ 7777120 was also observed in the NC/Nga mouse model of chronic allergic dermatitis (Ohsawa and Hirasawa, 2012). One 
explanation for the disconnect between some of the acute and chronic hapten models may be accounted for by differences in the cell types involved in the inflammation, i.e., Th1 versus Th2 cells.

Another disease typically associated with eosinophils and mast cells is asthma. The lack of effect for treating asthma with antagonists that target the $\mathrm{H}_{1} \mathrm{R}$ and $\mathrm{H}_{2} \mathrm{R}$ has led many to question the role of histamine in the disease (Thurmond et al., 2008). However, it is possible that histamine acts via the $\mathrm{H}_{4} \mathrm{R}$ to drive some of the pathophysiology of asthma. In support for a role of the $\mathrm{H}_{4} \mathrm{R}$ in asthma, polymorphisms in the gene have been associated with infection-induce asthma (Simon et al., 2012). In addition $\mathrm{H}_{4} \mathrm{R}$-deficient mice are protected in a mouse asthma model (Dunford et al., 2006). These mice have fewer eosinophils in bronchoalveolar lavage fluid, reduced inflammatory cytokines, and decreased antigen specific IgE and IgG1 levels after allergen challenge (Dunford et al., 2006). Treatment with the $\mathrm{H}_{4} \mathrm{R}$ antagonists JNJ 7777120, JNJ 10191584, or JNJ 39758979 during allergen challenge also reduced the eosinophilia (Dunford et al., 2006; Cowden et al., 2010a; Beermann et al., 2012; Neumann et al., 2013; Thurmond et al., 2014a). Improvement in lung function has also been shown upon treatment with an $\mathrm{H}_{4} \mathrm{R}$ antagonist and in $\mathrm{H}_{4} \mathrm{R}$-deficient mice (Cowden et al., 2010a; Hartwig et al., 2014). Similar effects have been reported in a guinea pig model, where JNJ 7777120 improved lung function, reduced inflammation, eosinophilia, and inflammatory mediator production in the lung after allergen challenge (Somma et al., 2013). All of these data point to a therapeutic potential for $\mathrm{H}_{4} \mathrm{R}$ antagonist for the treatment of asthma.

One unexpected finding in the mouse asthma models was that mast cells were not needed for the $\mathrm{H}_{4} \mathrm{R}$ response. Dunford et al. (2006) showed that the inhibition of lung eosinophilia and inflammatory cytokines levels by an $\mathrm{H}_{4} \mathrm{R}$ antagonist was still present in mice lacking mast cells. The model used in this case is known to be dependent on $\mathrm{T}$ cells and not mast cells (Komai et al., 2003), suggesting that $\mathrm{T}$ cells may be the main contributor to the $\mathrm{H}_{4} \mathrm{R}$ response. To support the effect of the $\mathrm{H}_{4} \mathrm{R}$ on $\mathrm{T}$ cells, JNJ 7777120 was dosed only around the sensitization in the asthma model when antigen specific $\mathrm{T}$ cells are being generated. As with the dosing at allergen challenge, treatment with the $\mathrm{H}_{4} \mathrm{R}$ antagonist at sensitization reduced the number of eosinophils and the inflammatory cytokines (Dunford et al., 2006). These results coupled with the fact that the $\mathrm{H}_{4} \mathrm{R}$ antagonists worked in models known to be $\mathrm{T}$ cell dependent suggested that the receptor was playing a role in the priming and activation of $\mathrm{T}$ cells. This effect is reflected in the reduction in Th2 cytokines such as IL-4, IL-5, and IL-13 in BAL fluid or upon restimulation of splenocytes or lymphocytes (Dunford et al., 2006; Cowden et al., 2010a; Somma et al., 2013; Hartwig et al., 2014). The activation of T cells may also be the primary target in the models of atopic dermatitis as reduction in Th2 cytokines have been reported in the skin after treatment with an $\mathrm{H}_{4} \mathrm{R}$ antagonist (Cowden et al., 2010b; Seike et al., 2010; Matsushita et al., 2012; Ohsawa and Hirasawa, 2012).

There are several possible mechanisms for the $\mathrm{H}_{4} \mathrm{R}$ effect on $\mathrm{T}$ cells. In both asthma and dermatitis models treatment with an $\mathrm{H}_{4} \mathrm{R}$ antagonist reduced the number of $\mathrm{T}$ cells at the site of inflammation (Cowden et al., 2010a; Mahapatra et al.,
2014). The reduction may be a result of decreases in the production of chemokines (Cowden et al., 2010a,b) or direct effects of histamine as a chemoattractant for T cells (Bryce et al., 2006; Morgan et al., 2007). Expression of the $\mathrm{H}_{4} \mathrm{R}$ has been reported on human Th2 cells and $\mathrm{H}_{4} \mathrm{R}$ agonists increased the expression of IL-31 (Gutzmer et al., 2009). The effects on T cells may also be indirect as there is evidence that the $\mathrm{H}_{4} \mathrm{R}$ is involved in dendritic cell function and may drive the response in asthma. When $\mathrm{H}_{4} \mathrm{R}$-deficient dendritic cells where used to polarize $\mathrm{T}$ cells in vitro, these $\mathrm{T}$ cells there not able to transfer disease in a mouse adoptive transfer asthma model (Hartwig et al., 2014). This was not the case when $\mathrm{H}_{4} \mathrm{R}$-deficient $\mathrm{T}$ cells were used. In addition, wild-type $\mathrm{T}$ cells could not transfer disease in $\mathrm{H}_{4} \mathrm{R}$-deficient mice suggesting that it is the $\mathrm{H}_{4} \mathrm{R}$ on other cells such as dendritic cells that are important for driving disease (Hartwig et al., 2014). One possible role for the $H_{4} \mathrm{R}$ in dendritic cells is in mediating migration of the cells to the site of interaction with $\mathrm{T}$ cells, since it has been shown that the migration of antigen positive dendritic cells from the skin to the lymph node was reduced upon treatment with an $\mathrm{H}_{4} \mathrm{R}$ antagonist (Cowden et al., 2010b). As for T cells, these effects may be a result of $\mathrm{H}_{4} \mathrm{R}$ directly mediating migration via histamine acting a chemoattractant (Gutzmer et al., 2005; Damaj et al., 2007; Bäumer et al., 2008; Gschwandtner et al., 2010, 2011) or indirectly by reduction in chemokine production (Cowden et al., 2010a,b). The $\mathrm{H}_{4} \mathrm{R}$ may also impact activation of dendritic cells. Dendritic cells from $\mathrm{H}_{4} \mathrm{R}$-deficient mice or treated in vitro with an $\mathrm{H}_{4} \mathrm{R}$ antagonists were defective in their ability to activate Th2 cells (Dunford et al., 2006). Similarly, when human monocyte derived dendritic cells were treated with JNJ 7777120 the levels of MHC and costimulatory molecules were reduced and these cells were unable to induce allergen-specific proliferation of $\mathrm{T}$ cells (Lundberg et al., 2011). In addition to effects on dendritic cell maturation, the $\mathrm{H}_{4} \mathrm{R}$ modulates cytokine and chemokine production by dendritic cells that may result in defective $\mathrm{T}$ cell activation (Gutzmer et al., 2005; Dunford et al., 2006; Dijkstra et al., 2008; Gschwandtner et al., 2010, 2011, 2012). Dendritic cells can be activated by endogenous danger signals action via toll-like receptors (TLRs). Activation of dendritic cells in vitro with TLR ligands leads to the production of cytokines and chemokines and this can be modulated by $\mathrm{H}_{4} \mathrm{R}$ antagonists (Gutzmer et al., 2005; Dunford et al., 2006; Dijkstra et al., 2008; Gschwandtner et al., 2010, 2011, 2012). In vivo $\mathrm{H}_{4} \mathrm{R}$ antagonist can inhibit LPS (a TLR ligand) induced production of inflammatory cytokines and this is also reduced in $\mathrm{H}_{4} \mathrm{R}$-deficient mice (Cowden et al., 2013). This link between TLR and $\mathrm{H}_{4} \mathrm{R}$ may important driving asthmatic responses since it has been shown that $\mathrm{H}_{4} \mathrm{R}$ antagonists are only effective in mouse asthma models when LPS is present (Cowden et al., 2013).

The role for the $\mathrm{H}_{4} \mathrm{R}$ in $\mathrm{T}$ cells pointed to possible roles in other disease that are thought to be $\mathrm{T}$ cell mediated. In particular the autoimmune disease rheumatoid arthritis is thought to be driven in part by $\mathrm{T}$ cell responses as evidenced by the clinical efficacy of abatacept, that targets the activation of $\mathrm{T}$ cells, and the fact that there is a strong genetic association with the human leukocyte antigen (HLA)-DRB1 and the presentation of 
antigens (Raychaudhuri et al., 2012; Gizinski and Fox, 2014). Based on this, the role of the $\mathrm{H}_{4} \mathrm{R}$ in preclinical models of rheumatoid arthritis has been explored. $\mathrm{H}_{4} \mathrm{R}$-deficient mice and mice treated with the $\mathrm{H}_{4} \mathrm{R}$ antagonist JNJ 28307474 were protected from disease in both a mouse collagen-induced arthritis and collagen antibody-induced arthritis model (Cowden et al., 2014). This was reflected in an improvement in disease severity score and in the histologic analysis of the joints. The antiinflammatory effects can be observed either with dosing at the onset of disease or at the peak of disease activity. A second selective $\mathrm{H}_{4} \mathrm{R}$ antagonist, JNJ 39758979, has also shown activity in the collagen-induced arthritis model (Savall et al., 2014). However, the effect on $\mathrm{T}$ cells may not translate into efficacy in all autoimmune diseases. $\mathrm{H}_{4} \mathrm{R}$-deficient mice or mice treated with an $\mathrm{H}_{4} \mathrm{R}$ antagonist had significantly worse disease in mouse experimental autoimmune encephalomyelitis models of multiple sclerosis (del Rio et al., 2012; Ballerini et al., 2013).

The collagen-induced arthritis model is known to be driven by the production of IL-17 from Th17 cells (Lubberts et al., 2001; Nakae et al., 2003; Lubberts et al., 2004). Treatment with the $\mathrm{H}_{4} \mathrm{R}$ antagonist in this model decreased the production of IL-17 from lymphocytes and reduced the number of IL-17 positive CD4 cells (Th17 cells) in the inguinal lymph node, but had no effect on the production of IFN $\gamma . \mathrm{H}_{4} \mathrm{R}$ antagonists also blocked the differentiation of Th17 cells in vitro and reduction in IL-17 production has also been reported in models of asthma and dermatitis (Dunford et al., 2006; Cowden et al., 2010b, 2014). As for the asthma model, the effects on $\mathrm{T}$ cells could be direct or indirect. For the collagen antibody-induced model, adoptive transfer of wild-type dendritic cells (splenic CD11c ${ }^{+}$cells) restored disease in $\mathrm{H}_{4} \mathrm{R}$-deficient animals suggesting that the $\mathrm{H}_{4} \mathrm{R}$ on antigen presenting cells was crucial for disease activity (Cowden et al., 2014). This is also suggested when Th17 development was studied directly in vivo using an adoptive transfer model. The $\mathrm{H}_{4} \mathrm{R}$ antagonist blocked the Th17 differentiation of transgenic $\mathrm{T}$ cells in vivo. In addition the transfer of wild-type transgenic $\mathrm{T}$ cells into $\mathrm{H}_{4} \mathrm{R}$-deficient host mice also resulted in a reduction in Th17 cells supporting the conclusion that the $\mathrm{H}_{4} \mathrm{R}$ on host antigen presenting cells is important (Cowden et al., 2014). However, this may not be the complete story as transfer of $\mathrm{H}_{4} \mathrm{R}$-deficient transgenic $\mathrm{T}$ cells into wild-type host also lead to a reduction in Th17 cells indicating that the $\mathrm{H}_{4} \mathrm{R}$ on $\mathrm{T}$ cells is also important. Expression the $\mathrm{H}_{4} \mathrm{R}$ has been reported on human and mouse Th17 cells (Mommert et al., 2012; Cowden et al., 2014). In isolated human Th17 cells $\mathrm{H}_{4} \mathrm{R}$ agonist increased the production of IL-17 and this was reduced by an $\mathrm{H}_{4} \mathrm{R}$ antagonist suggesting that the receptor can have a direct effect on Th17 cells (Mommert et al., 2012).

Pruritus is another process that has long been associated with histamine (for a review see Thurmond et al., 2014b). In fact, injection of histamine into the skin of humans causes the sensation of itching. Antihistamines that target the $\mathrm{H}_{1} \mathrm{R}$ have exhibited efficacy in reducing itch in a number of conditions such as acute urticaria and allergic rhinitis. However, the itch associated with other pruritic diseases such as atopic dermatitis is not well-controlled by these drugs. The discovery of the $\mathrm{H}_{4} \mathrm{R}$ prompted the exploration as to whether this receptor could be responsible for pruritic responses not driven by the $\mathrm{H}_{1} \mathrm{R}$. Injection of histamine into the skin of mice causes a scratching response. This response can be inhibited by the administration of $\mathrm{H}_{4} \mathrm{R}$ antagonists (Bell et al., 2004; Dunford et al., 2007; Yamaura et al., 2009; Shin et al., 2012; Savall et al., 2014). Histamine-induced scratching is also reduced in $\mathrm{H}_{4} \mathrm{R}$-deficient mice (Dunford et al., 2007). Injection of $\mathrm{H}_{4} \mathrm{R}$ agonists can induce scratching and this is inhibited with $\mathrm{H}_{4} \mathrm{R}$ antagonists or in $\mathrm{H}_{4} \mathrm{R}$-deficient mice (Dunford et al., 2007; Cowart et al., 2008; Liu et al., 2008; Koenig et al., 2010; $\mathrm{Yu}$ et al., 2010). $\mathrm{H}_{4} \mathrm{R}$ antagonists can also inhibit scratching in mice induced by substance $\mathrm{P}$, haptens, and in models of dermatitis (Rossbach et al., 2009; Yamaura et al., 2009; Cowden et al., 2010b; Suwa et al., 2011; Ohsawa and Hirasawa, 2012). These data have prompted the study of the anti-pruritic effects of $\mathrm{H}_{4} \mathrm{R}$ antagonists in humans.

\section{Clinical Data}

There have only been a few reports of clinical data with $\mathrm{H}_{4} \mathrm{R}$ antagonists. The compound with the most published information is JNJ 39758979. JNJ 39758979 is a potent and selective $\mathrm{H}_{4} \mathrm{R}$ antagonist that has efficacy in preclinical models of pruritus, dermatitis, asthma, and arthritis (Savall et al., 2014; Thurmond et al., 2014a). This $\mathrm{H}_{4} \mathrm{R}$ antagonist has been used to explore the role of the receptor in mediating histamine-induced pruritus in humans (NCT01068223). Over three periods subjects received either a single dose of JNJ 39758979, the $\mathrm{H}_{1} \mathrm{R}$ antagonist cetirizine, or placebo. At 2 and $6 \mathrm{~h}$ after dosing, histamine was injected intradermally into the skin of the forearm of each subject and the pruritic response was assessed by having the subject rate the itch sensation on 1-10 scale over a 10 min period (Kollmeier et al., 2014). JNJ 39758979 reduced the itch sensation induced by histamine at both 2 and $6 \mathrm{~h}$ after dosing, whereas placebo had no effects. Cetirizine was used as a positive control and it reduced the pruritic response at $6 \mathrm{~h}$ post-dose as expected. This data validates the preclinical findings in mice and shows that the $\mathrm{H}_{4} \mathrm{R}$ is involved in mediating pruritic responses in humans. This suggests that $\mathrm{H}_{4} \mathrm{R}$ antagonists will have utility in humans in treating pruritic conditions known to be mediated by histamine such as acute urticaria and allergic rhinitis. Of potential interest is the drug alcaftadine that is a topical ophthalmic solution indicated for the prevention of itching associated with allergic conjunctivitis. This compound has weak activity at the $\mathrm{H}_{4} \mathrm{R}$ as well as being a potent $\mathrm{H}_{1} \mathrm{R}$ antagonist and this differentiates it from other topical treatments such as olopatadine that has no $\mathrm{H}_{4} \mathrm{R}$ activity (GalloisBernos and Thurmond, 2012). Preclinical data indicate that the combination of $\mathrm{H}_{4} \mathrm{R}$ and $\mathrm{H}_{1} \mathrm{R}$ may yield better efficacy against pruritus than an $\mathrm{H}_{1} \mathrm{R}$ alone (Dunford et al., 2007; Nakano et al., 2009; Rossbach et al., 2009; Cowden et al., 2010b; Ohsawa and Hirasawa, 2012). This may also be true in humans as an analysis across two clinical efficacy studies indicated that alcaftadine exhibited greater efficacy in reducing ocular itch compared to 
olopatadine after conjunctival allergen challenge (McLaurin et al., 2014).

One pruritic condition where the itch is not well controlled by $\mathrm{H}_{1} \mathrm{R}$ antagonists is atopic dermatitis, which is a common inflammatory pruritic skin disease. Pruritus is one of the most common and characteristic symptoms of atopic dermatitis (Williams, 2005). Several clinical trials have been conducted to evaluate the efficacy of $\mathrm{H}_{1} \mathrm{R}$ antagonists for the reduction of pruritus associated with atopic dermatitis, with limited evidence for efficacy (Klein and Clark, 1999; Akdis et al., 2006; Saeki et al., 2009). These observations prompted the study of $\mathrm{H}_{4} \mathrm{R}$ antagonists in preclinical dermatology models and indicated that such antagonists could be efficacious (Cowden et al., 2010b; Seike et al., 2010; Suwa et al., 2011; Matsushita et al., 2012; Ohsawa and Hirasawa, 2012). Evidence that $\mathrm{H}_{4} \mathrm{R}$ can be efficacious against atopic dermatitis in humans has been provided in the clinical with JNJ 39758979. A phase 2a study in adults with moderate atopic dermatitis compared two doses of JNJ 39758979 versus placebo (Murata et al., 2015). Unfortunately, the study was terminated before all subjects completed the treatment period due to two cases of agranulocytosis that was most likely related to reactive metabolites of the compound and not to $\mathrm{H}_{4} \mathrm{R}$ antagonism (Murata et al., 2015). Post hoc analysis indicated evidence of efficacy. The primary efficacy was assessed at week 6 using eczema area and severity index (EASI) scores. There was a numerical reduction in the EASI score for both 100 and $300 \mathrm{mg}$ JNJ 39758979 compared to placebo, but these changes were not statically significant. The EASI score does not include any direct measurements of pruritus, which is the most common and characteristic symptom of atopic dermatitis, and therefore several secondary endpoints were include to assess pruritus. Across all of these endpoints there was a strong and nominally statistically significant reduction in the pruritus sensed by patients on JNJ 39758979 (Murata et al., 2015). Therefore although there are caveats with the interpretation of

\section{References}

Akdis, C. A., Akdis, M., Bieber, T., Bindslev-Jensen, C., Boguniewicz, M., Eigenmann, P., et al. (2006). Diagnosis and treatment of atopic dermatitis in children and adults: European academy of allergology and clinical immunology/American academy of allergy, asthma and immunology/PRACTALL consensus report. J. Allergy Clin. Immunol. 118, 152-169. doi: 10.1016/j.jaci.2006.03.045

Altenbach, R. J., Adair, R. M., Bettencourt, B. M., Black, L. A., Fix-Stenzel, S. R., Gopalakrishnan, S. M., et al. (2008). Structure-activity studies on a series of a 2-aminopyrimidine-containing histamine $\mathrm{H} 4$ receptor ligands. J. Med. Chem. 51, 6571-6580. doi: 10.1021/jm8005959

Arrang, J. M., Garbarg, M., and Schwartz, J. C. (1983). Autoinhibition of brain histamine release mediated by a novel class (H3) of histamine receptor. Nature 302, 832-837. doi: 10.1038/302832a0

Ash, A. S. F., and Schild, J. O. (1966). Receptors mediating some action of histamine. Br. J. Pharmacol. 27, 427-439.

Baeumer, W., Stahl, J., Sander, K., Petersen, L. J., Paps, J., Stark, H., et al. (2011). Lack of preventing effect of systemically and topically administered histamine $\mathrm{H} 1$ or $\mathrm{H} 4$ receptor antagonists in a dog model of acute atopic dermatitis. Exp. Dermatol. 20, 577-581. doi: 10.1111/j.1600-0625.2011.01268.x

Ballerini, C., Aldinucci, A., Luccarini, I., Galante, A., Manuelli, C., Blandina, P., et al. (2013). Antagonism of histamine H4 receptors exacerbates clinical and pathological signs of experimental autoimmune encephalomyelitis. $\mathrm{Br}$. J. Pharmacol. 170, 67-77. doi: 10.1111/bph.12263 the results and issues with the safety of JNJ 39758979, it appears that other safer $\mathrm{H}_{4} \mathrm{R}$ antagonists could have utility in the treatment of atopic dermatitis especially with respect to reducing pruritus.

In addition to the published studies a study with JNJ 39758979 in patients with persistent asthma (NCT00946569) has been completed, but no data has been reported. In addition to this other $\mathrm{H}_{4} \mathrm{R}$ antagonists have been reported to be in the clinic such as UR-63325, PF-3893787, and toreforant (JNJ 38518168), the first $\mathrm{H}_{4} \mathrm{R}$ antagonist with a generic name. ClinicalTrials.gov indicates that UR-63325 has completed a nasal allergen challenge study in patients with allergic rhinitis (NCT01260753) and PF-3893787 a bronchial allergen challenge study in patients with asthma (NCT00856687), but no results have been reported. Toreforant has completed efficacy studies in patients with rheumatoid arthritis (NCT01679951, NCT00941707, and NCT01862224). Results for these studies have not been reported, but it was noted that a dose range finding study in rheumatoid arthritis (NCT01679951) was terminated for lack of efficacy. Studies with toreforant in patients with asthma (NCT01823016) and psoriasis (NCT02295865) were ongoing as of February 2015.

\section{Conclusion}

The story of the $\mathrm{H}_{4} \mathrm{R}$ provides an excellent case study for the deorphanization of a novel receptor and the translation of this into clinical efficacy in humans. The gene for the receptor was discovered via genomic homology searches and reverse pharmacology led to the identification of its role in immune and pruritic responses. This work has now resulted in the first reports of clinical efficacy for $\mathrm{H}_{4} \mathrm{R}$ antagonists and point to the potential of these ligands as future drugs for the treatment of a variety of indications.

Barger, G., and Dale, H. H. (1910). 4- $\beta$-Aminoethylglyoxaline ( $\beta$ Aminazolylethylamine) and the other active principles of ergot. J. Chem. Soc. Trans. 97, 2592-2595. doi: 10.1039/ct9109702592

Barnard, R., Barnard, A., Salmon, G., Liu, W., and Sreckovic, S. (2008). Histamineinduced actin polymerization in human eosinophils: an imaging approach for histamine H4 receptor. Cytometry A 73, 299-304. doi: 10.1002/cyto.a. 20514

Bäumer, W., Wendorff, S., Gutzmer, R., Werfel, T., Dijkstra, D., Chazot, P., et al. (2008). Histamine H4 receptors modulate dendritic cell migration through skin - immunomodulatory role of histamine. Allergy 63, 1387-1394. doi: 10.1111/j.1398-9995.2008.01720.x

Beermann, S., Glage, S., Jonigk, D., Seifert, R., and Neumann, D. (2012). Opposite effects of mepyramine on JNJ 7777120-induced amelioration of experimentally induced asthma in mice in sensitization and provocation. PLOS ONE 7:e30285. doi: 10.1371/journal.pone.0030285

Bell, J. K., McQueen, D. S., and Rees, J. L. (2004). Involvement of histamine $\mathrm{H}_{4}$ and $\mathrm{H}_{1}$ receptors in scratching induced by histamine receptor agonists in BalbC mice. Br. J. Pharmacol. 142, 374-380. doi: 10.1038/sj.bjp. 0705754

Black, J. W., Duncan, W. A. M., Durant, C. J., Ganellin, C. R., and Parsons, E. M. (1972). Definition and antagonism of histamine H2-receptors. Nature 236 385-390. doi: 10.1038/236385a0

Bryce, P. J., Mathias, C. B., Harrison, K. L., Watanabe, T., Geha, R. S., and Oettgen, H. C. (2006). The H1 histamine receptor regulates allergic lung responses. J. Clin. Invest. 116, 1624-1632. doi: 10.1172/JCI26150 
Buckland, K. F., Williams, T. J., and Conroy, D. M. (2003). Histamine induces cytoskeletal changes in human eosinophils via the $\mathrm{H}_{4}$ receptor. $\mathrm{Br}$. J. Pharmacol. 140, 1117-1127. doi: 10.1038/sj.bjp.0705530

Cheng, Y., and Prusoff, W. H. (1973). Relation between the inhibition constant K1) and the concentration of inhibitor which causes fifty per cent inhibition (I50) of an enzymic reaction. Biochem. Pharmacol. 22, 3099-3108. doi: 10.1016/0006-2952(73)90196-2

Clark, R. A. F., Gallin, J. I., and Kaplan, A. P. (1975). Selective eosinophil chemotactic activity of histamine. J. Exp. Med. 142, 1462-1476. doi: 10.1084/jem.142.6.1462

Clark, R. A. F., Sandler, J. A., Gallin, J. I., and Kaplan, A. P. (1977). Histamine modulation of eosinophil migration. J. Immunol. 118, 137-145.

Coruzzi, G., Adami, M., Guaita, E., de Esch, I. J. P., and Leurs, R. (2007). Antiinflammatory and antinociceptive effects of the selective histamine $\mathrm{H}_{4}$-receptor antagonists JNJ7777120 and VUF6002 in a rat model of carrageenan-induced acute inflammation. Eur. J. Pharmacol. 563, 240-244. doi: 10.1016/j.ejphar.2007.02.026

Cowart, M. D., Altenbach, R. J., Liu, H., Hsieh, G. C., Drizin, I., Milicic, I., et al. (2008). Rotationally constrained 2,4-Diamino-5,6-disubstituted pyrimidines: a new class of histamine $\mathrm{H} 4$ receptor antagonists with improved druglikeness and in vivo efficacy in pain and inflammation models. J. Med. Chem. 51, 6547-6557. doi: $10.1021 /$ jm800670r

Cowden, J. M., Riley, J. P., Ma, J. Y., Thurmond, R. L., and Dunford, P. J. (2010a). Histamine $\mathrm{H} 4$ receptor antagonism diminishes existing airway inflammation and dysfunction via modulation of Th2 cytokines. Respir. Res. 11:86. doi: 10.1186/1465-9921-11-86

Cowden, J. M., Zhang, M., Dunford, P. J., and Thurmond, R. L. (2010b). The histamine $\mathrm{H}_{4}$ receptor mediates inflammation and pruritus in Th2dependent dermal inflammation. J. Invest. Dermatol. 130, 1023-1033. doi: 10.1038/jid.2009.358

Cowden, J. M., Yu, F., Banie, H., Farahani, M., Ling, P., Nguyen, S., et al. (2014). The histamine H4 receptor mediates inflammation and Th17 responses in preclinical models of arthritis. Ann. Rheum. Dis. 73, 600-608. doi: 10.1136/annrheumdis-2013-203832

Cowden, J. M., Yu, F., Challapalli, M., Huang, J. F., Kim, S., Fung-Leung, W. P., et al. (2013). Antagonism of the histamine H4 receptor reduces LPS-induced TNF production in vivo. Inflamm. Res. 62, 599-607. doi: 10.1007/s00011-0130612-5

Dale, H. H., and Laidlaw, P. P. (1911). The physiological action of B-Iminazolylethylamine. J. Physiol. 41, 318-344. doi: 10.1113/jphysiol.1910.sp001406

Damaj, B. B., Becerra, C. B., Esber, H. J., Wen, Y., and Maghazachi, A. A. (2007). Functional expression of $\mathrm{H}_{4}$ histamine receptor in human natural killer cells, monocytes, and dendritic cells. J. Immunol. 179, 7907-7915. doi: 10.4049/jimmunol.179.11.7907

De Backer, M. D., Gommeren, W., Moereels, H., Nobels, G., Van Gompel, P., Leysen, J. E., et al. (1993). Genomic cloning, heterologous expression and pharmacological characterization of a human histamine $\mathrm{H} 1$ receptor. Biochem. Biophys. Res. Commun. 197, 1601-1608. doi: 10.1006/bbrc.1993.2662

del Rio, R., Noubade, R., Saligrama, N., Wall, E. H., Krementsov, D. N., Poynter, M. E., et al. (2012). Histamine H4 receptor optimizes T regulatory cell frequency and facilitates anti-inflammatory responses within the central nervous system. J. Immunol. 188, 541-547. doi: 10.4049/jimmunol.1101498

Desai, P., and Thurmond, R. L. (2011). Histamine H4 receptor activation enhances LPS-induced IL-6 production in mast cells via ERK and PI3K activation. Eur. J. Immunol. 41, 1764-1773. doi: 10.1002/eji.201040932

Dijkstra, D., Stark, H., Chazot, P. L., Shenton, F. C., Leurs, R., Werfel, T., et al. (2008). Human inflammatory dendritic epidermal cells express a functional histamine $\mathrm{H}_{4}$ receptor. J. Invest. Dermatol. 128, 1696-1703. doi: 10.1038/sj.jid.5701250

Dunford, P. J., O’Donnell, N., Riley, J. P., Williams, K. N., Karlsson, L., and Thurmond, R. L. (2006). The histamine $\mathrm{H}_{4}$ receptor mediates allergic airway inflammation by regulating the activation of $\mathrm{CD}^{+} \mathrm{T}$ cells. J. Immunol. 176, 7062-7070. doi: 10.4049/jimmunol.176.11.7062

Dunford, P. J., Williams, K. N., Desai, P. J., Karlsson, L., McQueen, D., and Thurmond, R. L. (2007). Histamine $\mathrm{H}_{4}$ receptor antagonists are superior to traditional antihistamines in the attenuation of experimental pruritus. J. Allergy Clin. Immunol. 119, 176-183. doi: 10.1016/j.jaci.2006.08.034
Gallois-Bernos, A. C., and Thurmond, R. L. (2012). Alcaftadine, a new antihistamine with combined antagonist activity at histamine $\mathrm{H} 1, \mathrm{H} 2$, and H4 receptors. J. Recept. Ligand Channel Res. 5, 9-20. doi: 10.2147/JRLCR. S39369

Gantz, I., Munzert, G., Tashiro, T., Schaffer, M., Wang, L., DelValle, J., et al. (1991). Molecular cloning of the human histamine $\mathrm{H} 2$ receptor. Biochem. Biophys. Res. Commun. 178, 1386-1392. doi: 10.1016/0006-291X(91)91047-G

Gizinski, A. M., and Fox, D. A. (2014). T cell subsets and their role in the pathogenesis of rheumatic disease. Curr. Opin. Rheumatol. 26, 204-210. doi: 10.1097/BOR.0000000000000036

Godot, V., Arock, M., Garcia, G., Capel, F., Flys, C., Dy, M., et al. (2007). H4 histamine receptor mediates optimal migration of mast cell precursors to CXCL12. J. Allergy Clin. Immunol. 120, 827-834. doi: 10.1016/j.jaci.2007.05.046

Gschwandtner, M., Bunk, H., Koether, B., Thurmond, R. L., Kietzmann, M., Werfel, T., et al. (2012). Histamine down-regulates IL-27 production in antigenpresenting cells. J. Leukoc. Biol. 92, 21-29. doi: 10.1189/jlb.0111017

Gschwandtner, M., Mommert, S., Koether, B., Werfel, T., and Gutzmer, R. (2011). The histamine $\mathrm{H} 4$ receptor is highly expressed on plasmacytoid dendritic cells in psoriasis and histamine regulates their cytokine production and migration. J. Invest. Dermatol. 131, 1668-1676. doi: 10.1038/jid.2011.72

Gschwandtner, M., Rossbach, K., Dijkstra, D., Baeumer, W., Kietzmann, M., Stark, H., et al. (2010). Murine and human Langerhans cells express a functional histamine H4 receptor: modulation of cell migration and function. Allergy 65, 840-849. doi: 10.1111/j.1398-9995.2009.02279.x

Gutzmer, R., Diestel, C., Mommert, S., Koether, B., Stark, H., Wittmann, M., et al. (2005). Histamine $\mathrm{H}_{4}$ receptor stimulation suppresses IL-12p70 production and mediates chemotaxis in human monocyte-derived dendritic cells. J. Immunol. 174, 5224-5232. doi: 10.4049/jimmunol.174.9.5224

Gutzmer, R., Mommert, S., Gschwandtner, M., Zwingmann, K., Stark, H., and Werfel, T. (2009). The histamine H4 receptor is functionally expressed on TH2 cells. J. Allergy Clin. Immunol. 123, 619-625. doi: 10.1016/j.jaci.2008.12.1110

Hartwig, C., Munder, A., Glage, S., Wedekind, D., Schenk, H., Seifert, R., et al. (2014). The histamine H4-receptor (H4R) regulates eosinophilic inflammation in ovalbumin-induced experimental allergic asthma in mice. Eur. J. Immunol. doi: 10.1002/eji.201445179 [Epub ahead of print].

Hofstra, C. L., Desai, P. J., Thurmond, R. L., and Fung-Leung, W.-P. (2003). Histamine $\mathrm{H}_{4}$ receptor mediates chemotaxis and calcium mobilization of mast cells. J. Pharmacol. Exp. Ther. 305, 1212-1221. doi: 10.1124/jpet.102.046581

Hough, L. B. (2001). Genomics meets histamine receptors: new subtypes, new receptors. Mol. Pharmacol. 59, 415-419.

Hsieh, G. C., Chandran, P., Salyers, A. K., Pai, M., Zhu, C. Z., Wensink, E. J., et al. (2010). H4 receptor antagonism exhibits anti-nociceptive effects in inflammatory and neuropathic pain models in rats. Pharmacol. Biochem. Behav. 95, 41-50. doi: 10.1016/j.pbb.2009.12.004

Jablonowski, J. A., Grice, C. A., Chai, W., Dvorak, C. A., Venable, J. D., Kwok, A. K., et al. (2003). The first potent and selective non-imidazole human histamine $\mathrm{H}_{4}$ receptor antagonists. J. Med. Chem. 46, 3957-3960. doi: 10.1021/jm0341047

Jemima, E. A., Prema, A., and Thangam, E. B. (2014). Functional characterization of histamine H4 receptor on human mast cells. Mol. Immunol. 62, 19-28. doi: 10.1016/j.molimm.2014.05.007

Klein, P. A., and Clark, R. A. F. (1999). An evidence-based review of the efficacy of antihistamines in relieving pruritus in atopic dermatitis. Arch. Dermatol. 135, 1522-1525. doi: 10.1001/archderm.135.12.1522

Koenig, J. R., Liu, H., Drizin, I., Witte, D. G., Carr, T. L., Manelli, A. M., et al. (2010). Rigidified 2-aminopyrimidines as histamine $\mathrm{H} 4$ receptor antagonists: effects of substitution about the rigidifying ring. Bioorg. Med. Chem. Lett. 20, 1900-1904. doi: 10.1016/j.bmcl.2010.01.131

Kollmeier, A., Francke, K., Chen, B., Dunford, P. J., Greenspan, A. J., Xia, Y., et al. (2014). The H4 receptor antagonist, JNJ 39758979, is effective in reducing histamine-induced pruritus in a randomized clinical study in healthy subjects. J. Pharmacol. Exp. Ther. 350, 181-187. doi: 10.1124/jpet.114.215749

Komai, M., Tanaka, H., Masuda, T., Nagao, K., Ishizaki, M., Sawada, M., et al. (2003). Role of Th2 responses in the development of allergen-induced airway remodelling in a murine model of allergic asthma. Br. J. Pharmacol. 138, 912-920. doi: 10.1038/sj.bjp.0705105

Lim, H. D., van Rijn, R. M., Ling, P., Bakker, R. A., Thurmond, R. L., and Leurs, R. (2005). Evaluation of histamine H1-, H2-, and H3-receptor ligands at the human histamine $\mathrm{H} 4$ receptor: identification of 4-methylhistamine as 
the first potent and selective H4 receptor agonist. J. Pharmacol. Exp. Ther. 314, 1310-1321. doi: 10.1124/jpet.105.087965

Ling, P., Ngo, K., Nguyen, S., Thurmond, R. L., Edwards, J. P., Karlsson, L., et al. (2004). Histamine $\mathrm{H}_{4}$ receptor mediates eosinophil chemotaxis with cell shape change and adhesion molecule upregulation. Br. J. Pharmacol. 142, 161-171. doi: 10.1038/sj.bjp.0705729

Liu, C., Ma, X.-J., Jiang, X., Wilson, S. J., Hofstra, C. L., Blevitt, J., et al. (2001). Cloning and pharmacological characterization of a fourth histamine receptor $\left(\mathrm{H}_{4}\right)$ expressed in bone marrow. Mol. Pharmacol. 59, 420-426.

Liu, H., Altenbach, R. J., Carr, T. L., Chandran, P., Hsieh, G. C., Lewis, L. G. R., et al. (2008). cis-4-(Piperazin-1-yl)-5,6,7a,8,9,10,11,11a-octahydrobenzofuro[2,3h] quinazolin-2-amine (A-987306), a new histamine H4R antagonist that blocks pain responses against Carrageenan-induced hyperalgesia. J. Med. Chem. 51, 7094-7098. doi: 10.1021/jm8007618

Lovenberg, T. W., Roland, B. L., Wilson, S. J., Jiang, X., Pyati, J., Huvar, A., et al. (1999). Cloning and functional expression of the human histamine H3 receptor. Mol. Pharmacol. 55, 1101-1107.

Lubberts, E., Joosten, L. A., Oppers, B., van den Bersselaar, L., Coenen-de Roo, C. J., Kolls, J. K., et al. (2001). IL-1-independent role of IL-17 in synovial inflammation and joint destruction during collagen-induced arthritis. J. Immunol. 167, 1004-1013. doi: 10.4049/jimmunol.167.2.1004

Lubberts, E., Koenders, M. I., Oppers-Walgreen, B., van den Bersselaar, L., Coenende, R. C. J., Joosten, L. A., et al. (2004). Treatment with a neutralizing antimurine interleukin-17 antibody after the onset of collagen-induced arthritis reduces joint inflammation, cartilage destruction, and bone erosion. Arthritis Rheum. 50, 650-659. doi: 10.1002/art.20001

Lundberg, K., Broos, S., Greiff, L., Borrebaeck, C. A. K., and Lindstedt, M. (2011). Histamine $\mathrm{H} 4$ receptor antagonism inhibits allergen-specific T-cell responses mediated by human dendritic cells. Eur. J. Pharmacol. 651, 197-204. doi: 10.1016/j.ejphar.2010.10.065

Mahapatra, S., Albrecht, M., Behrens, B., A.-Dittrich, M., Jirmo, A., Behrens, G., et al. (2014). Delineating the role of histamine-1-and-4-receptors in a mouse model of th2-dependent antigen-specific skin inflammation. PLoS ONE 9:e87296. doi: 10.1371/journal.pone.0087296

Matsushita, A., Seike, M., Okawa, H., Kadawaki, Y., and Ohtsu, H. (2012). Advantages of histamine $\mathrm{H} 4$ receptor antagonist usage with $\mathrm{H} 1$ receptor antagonist for the treatment of murine allergic contact dermatitis. Exp. Dermatol. 21, 714-715. doi: 10.1111/j.1600-0625.2012.01559.x

McLaurin, E. B., Marsico, N. P., Ackerman, S. L., Ciolino, J. B., Williams, J. M., Villanueva, L., et al. (2014). Ocular itch relief with alcaftadine $0.25 \%$ versus olopatadine $0.2 \%$ in allergic conjunctivitis: pooled analysis of two multicenter randomized clinical trials. Adv. Ther. 31, 1059-1071. doi: 10.1007/s12325-0140155-3

Mirzahosseini, A., Dalmadi, B., and Csutora, P. (2013). Histamine receptor H4 regulates mast cell degranulation and IgE induced FceRI upregulation in murine bone marrow-derived mast cells. Cell. Immunol. 283, 38-44. doi: 10.1016/j.cellimm.2013.05.006

Mommert, S., Gschwandtner, M., Koether, B., Gutzmer, R., and Werfel, T. (2012). Human memory Th17 cells express a functional histamine $\mathrm{H} 4$ receptor. Am. J. Pathol. 180, 177-185. doi: 10.1016/j.ajpath.2011.09.028

Morgan, R. K., McAllister, B., Cross, L., Green, D. S., Kornfeld, H., Center, D. M., et al. (2007). Histamine 4 receptor activation induces recruitment of FoxP3 ${ }^{+}$ $\mathrm{T}$ cells and inhibits allergic asthma in a murine model. J. Immunol. 178, 8081-8089. doi: 10.4049/jimmunol.178.12.8081

Morse, K. L., Behan, J., Laz, T. M., West, R. E. Jr., Greenfeder, S. A., Anthes, J. C., et al. (2001). Cloning and characterization of a novel human histamine receptor. J. Pharmacol. Exp. Ther. 296, 1058-1066.

Murata, Y., Song, M., Kikuchi, H., Hisamichi, K., Xu, X. L., Greenspan, A., et al. (2015). Phase 2a, randomized, double-blind, placebo-controlled, multicenter, parallel-group study of a H4R-antagonist (JNJ-39758979) in Japanese adults with moderate atopic dermatitis. J. Dermatol. 42, 129-139. doi: 10.1111/13468138.12726

Nakae, S., Saijo, S., Horai, R., Sudo, K., Mori, S., and Iwakura, Y. (2003). IL-17 production from activated $\mathrm{T}$ cells is required for the spontaneous development of destructive arthritis in mice deficient in IL-1 receptor antagonist. Proc. Natl. Acad. Sci. U.S.A. 100, 5986-5990. doi: 10.1073/pnas.1035999100

Nakamura, T., Itadani, H., Hidaka, Y., Ohta, M., and Tanaka, K. (2000). Molecular cloning and characterization of a new human histamine receptor,
HH4R. Biochem. Biophys. Res. Commun. 279, 615-620. doi: 10.1006/bbrc.20 00.4008

Nakano, Y., Takahashi, Y., Ono, R., Kurata, Y., Kagawa, Y., and Kamei, C. (2009). Role of histamine H4 receptor in allergic conjunctivitis in mice. Eur. J. Pharmacol. 608, 71-75. doi: 10.1016/j.ejphar.2009. 02.035

Neumann, D., Beermann, S., Burhenne, H., Glage, S., Hartwig, C., and Seifert, R. (2013). The dual H3/4R antagonist thioperamide does not fully mimic the effects of the 'standard' H4R antagonist JNJ 7777120 in experimental murine asthma. Naunyn Schmiedebergs Arch. Pharmacol. 386, 983-990. doi: 10.1007/s00210-013-0898-4

Nguyen, T., Shapiro, D. A., George, S. R., Setola, V., Lee, D. K., Cheng, R., et al. (2001). Discovery of a novel member of the histamine receptor family. Mol. Pharmacol. 59, 427-433.

Oda, T., Morikawa, N., Saito, Y., Masuho, Y., and Matsumoto, S. (2000). Molecular cloning and characterization of a novel type of histamine receptor preferentially expressed in leukocytes. J. Biol. Chem. 275, 36781-36786. doi: 10.1074/jbc.M006480200

Ohsawa, Y., and Hirasawa, N. (2012). The antagonism of histamine H1 and $\mathrm{H} 4$ receptors ameliorates chronic allergic dermatitis via anti-pruritic and anti-inflammatory effects in NC/Nga mice. Allergy 67, 1014-1022. doi: 10.1111/j.1398-9995.2012.02854.x

O’Reilly, M., Alpert, R., Jenkinson, S., Gladue, R. P., Foo, S., Trim, S., et al. (2002). Identification of a histamine $\mathrm{H}_{4}$ receptor on human eosinophils-role in eosinophil chemotaxis. J. Recept. Signal Transduct. Res. 22, 431-448. doi: 10.1081/RRS-120014612

Raible, D. G., Lenahan, T., Fayvilevich, Y., Kosinski, R., and Schulman, E. S. (1994). Pharmacologic characterization of a novel histamine receptor on human eosinophils. Am. J. Respir. Crit. Care Med. 149, 1506-1511. doi: 10.1164/ajrccm.149.6.8004306

Raible, D. G., Schulman, E. S., DiMuzio, J., Cardillo, R., and Post, T. J. (1992). Mast cell mediators prostaglandin-D2 and histamine activate human eosinophils. J. Immunol. 148, 3536-3542.

Raychaudhuri, S., Sandor, C., Stahl, E. A., Freudenberg, J., Lee, H. S., Jia, X., et al. (2012). Five amino acids in three HLA proteins explain most of the association between MHC and seropositive rheumatoid arthritis. Nat. Genet. 44, 291-296. doi: 10.1038/ng.1076

Reher, T. M., Neumann, D., Buschauer, A., and Seifert, R. (2012). Incomplete activation of human eosinophils via the histamine H4-receptor: evidence for ligand-specific receptor conformations. Biochem. Pharmacol. 84, 192-203. doi: 10.1016/j.bcp.2012.04.004

Rosethorne, E. M., and Charlton, S. J. (2011). Agonist-biased signaling at the histamine H4 receptor: JNJ7777120 recruits $\beta$-arrestin without activating G proteins. Mol. Pharmacol. 79, 749-757. doi: 10.1124/mol.110. 068395

Rossbach, K., Wendorff, S., Sander, K., Stark, H., Gutzmer, R., Werfel, T., et al. (2009). Histamine H4 receptor antagonism reduces hapten-induced scratching behaviour but not inflammation. Exp. Dermatol. 18, 57-63. doi: 10.1111/j.16000625.2008.00762.x

Sabroe, I., Hartnell, A., Jopling, L. A., Bel, S., Ponath, P. D., Pease, J. E., et al. (1999). Differential regulation of eosinophil chemokine signaling via CCR3 and non-CCR3 pathways. J. Immunol. 162, 2946-2955.

Saeki, H., Furue, M., Furukawa, F., Hide, M., Ohtsuki, M., Katayama, I., et al. (2009). Guidelines for management of atopic dermatitis. J. Dermatol. 36, 563577. doi: 10.1111/j.1346-8138.2009.00706.x

Savall, B. M., Chavez, F., Tays, K., Dunford, P., Cowden, J., Hack, M. D., et al. (2014). Discovery and SAR of 6-Alkyl-2,4-diaminopyrimidines as H4 receptor antagonists. J. Med. Chem. 57, 2429-2439. doi: 10.1021/jm4 $01727 \mathrm{~m}$

Seifert, R., Schneider, E. H., Dove, S., Brunskole, I., Neumann, D., Strasser, A., et al. (2011). Paradoxical stimulatory effects of the "standard" histamine H4-receptor antagonist JNJ7777120: the H4-receptor joins the club of 7TM receptors exhibiting functional selectivity. Mol. Pharmacol. 79, 631-638. doi: 10.1124/mol.111.071266

Seike, M., Furuya, K., Omura, M., Hamada-Watanabe, K., Matsushita, A., and Ohtsu, H. (2010). Histamine H4 receptor antagonist ameliorates chronic allergic contact dermatitis induced by repeated challenge. Allergy 65, 319-326. doi: 10.1111/j.1398-9995.2009.02240.x 
Shin, N., Covington, M., Bian, D., Zhuo, J., Bowman, K., Li, Y., et al. (2012). INCB38579, a novel and potent histamine H4 receptor small molecule antagonist with anti-inflammatory pain and anti-pruritic functions. Eur. J. Pharmacol. 675, 47-56. doi: 10.1016/j.ejphar.2011.11.027

Simon, T., Semsei, A. F., Ungvari, I., Hadadi, E., Virag, V., Nagy, A., et al. (2012). Asthma endophenotypes and polymorphisms in the histamine receptor HRH4 gene. Int. Arch. Allergy Immunol. 159, 109-120. doi: 10.1159/000335919

Somma, T., Cinci, L., Formicola, G., Pini, A., Thurmond, R., Ennis, M., et al. (2013). A selective antagonist of histamine H4 receptors prevents antigen-induced airway inflammation and bronchoconstriction in guinea pigs: involvement of lipocortin-1. Br. J. Pharmacol. 170, 200-213. doi: 10.1111/ bph. 12264

Strakhova, M. I., Cuff, C. A., Manelli, A. M., Carr, T. L., Witte, D. G., Baranowski, J. L., et al. (2009). In vitro and in vivo characterization of A-940894: a potent histamine $\mathrm{H} 4$ receptor antagonist with anti-inflammatory properties. $\mathrm{Br}$. J. Pharmacol. 157, 44-54. doi: 10.1111/j.1476-5381.2009.00236.x

Suwa, E., Yamaura, K., Oda, M., Namiki, T., and Ueno, K. (2011). Histamine $\mathrm{H} 4$ receptor antagonist reduces dermal inflammation and pruritus in a hapten-induced experimental model. Eur. J. Pharmacol. 667, 383-388. doi: 10.1016/j.ejphar.2011.05.037

Thurmond, R. L., Chen, B., Dunford, P. J., Greenspan, A. J., Karlsson, L., La, D., et al. (2014a). Clinical and preclinical characterization of the histamine H4 receptor antagonist JNJ-39758979. J. Pharmacol. Exp. Ther. 349, 176-184. doi: 10.1124/jpet.113.211714

Thurmond, R. L., Kazerouni, K., Chaplan, S. R., and Greenspan, A. J. (2014b). "Peripheral neuronal mechanism of itch: histamine and itch" in Itch: Mechanisms and Treatment, Chap. 10, eds E. Carstens and T. Akiyama (Boca Raton, FL: CRC Press), 143-192.

Thurmond, R. L., Desai, P. J., Dunford, P. J., Fung-Leung, W.-P., Hofstra, C. L., Jiang, W., et al. (2004). A potent and selective histamine $\mathrm{H}_{4}$ receptor antagonist with anti-inflammatory properties. J. Pharmacol. Exp. Ther. 309, 404-413. doi: 10.1124/jpet.103.061754
Thurmond, R. L., Gelfand, E. W., and Dunford, P. J. (2008). The role of histamine $\mathrm{H}_{1}$ and $\mathrm{H}_{4}$ receptors in allergic inflammation: the search for new antihistamines. Nat. Rev. Drug Discov. 7, 41-53. doi: 10.1038/nrd2465

Varga, C., Horvath, K., Berko, A., Thurmond, R. L., Dunford, P. J., and Whittle, B. J. R. (2005). Inhibitory effects of histamine $\mathrm{H}_{4}$ receptor antagonists on experimental colitis in the rat. Eur. J. Pharmacol. 522, 130-138. doi: 10.1016/j.ejphar.2005.08.045

Wells, J. A., Morris, H. C., Bull, H. B., and Dragstedt, C. A. (1945). Observations on the nature of the antagonism of histamine by $\beta$-dimethylaminoethyl benzhydryl ether (benadryl). J. Pharmacol. Exp. Ther. 85, 122-128.

Williams, H. C. (2005). Clinical practice. Atopic dermatitis. N. Engl. J. Med. 352, 2314-2324. doi: 10.1056/NEJMcp042803

Yamaura, K., Oda, M., Suwa, E., Suzuki, M., Sato, H., and Ueno, K. (2009). Expression of histamine H4 receptor in human epidermal tissues and attenuation of experimental pruritus using $\mathrm{H} 4$ receptor antagonist. J. Toxicol. Sci. 34, 427-431. doi: 10.2131/jts.34.427

Yu, F., Wolin, R. L., Wei, J., Desai, P. J., McGovern, P. M., Dunford, P. J., et al. (2010). Pharmacological characterization of oxime agonists of the histamine H4 receptor. J. Receptor Ligand Channel Res. 3, 37-49. doi: 10.2147/JRLCR.S6468

Zhu, Y., Michalovich, D., Wu, H., Tan, K. B., Dytko, G. M., Mannan, I. J., et al. (2001). Cloning, expression, and pharmacological characterization of a novel human histamine receptor. Mol. Pharmacol. 59, 434-441.

Conflict of Interest Statement: Author is an employee and stock holder of Johnson and Johnson, the parent company of Janssen Research \& Development.

Copyright (c) 2015 Thurmond. This is an open-access article distributed under the terms of the Creative Commons Attribution License (CC BY). The use, distribution or reproduction in other forums is permitted, provided the original author (s) or licensor are credited and that the original publication in this journal is cited, in accordance with accepted academic practice. No use, distribution or reproduction is permitted which does not comply with these terms. 